\title{
Perspektif Etika Bisnis Islam Pada Sistem Konsinyasi Dalam Strategi Reseller
}

\author{
Muhammad Khoirul Fikri \\ Institut Agama Islam Negeri Pekalongan \\ muhammad.khoirul.fikri@iainpekalongan.ac.id
}

\begin{abstract}
The present study explores business behavior and consignment arrangements with suppliers demonstrated by Hamzah Batik, a batik and souvenir center in Yogyakarta,regarding the perspective of Islamic business ethics. A qualitative approach was employed in this field research. The data were collected through interviews with resellers, suppliers, and courier service and logistics companies dealing with Hamzah Batik as well as observation and documentation. The findings expose that Hamzah Batik performed positive business behavior concerning Islamic business ethics. It is worth noticing that the shopping centeremphasized visionary business leadership and managed a good consignment system with its suppliers. Additionally, both parties engaged in beneficial business cooperation. Hamzah Batik served the suppliers' rights and obligations. This study promotes that corporate social responsibility and trust provided with suppliers constitute a very pivotal element in maintaining a successful business partnership.
\end{abstract}

Keywords: Islamic business ethics, resellers, consignment

Penelitian ini bertujuan untuk mengetahui bagaimana perilaku bisnis Hamzah Batik Yogyakarta dalam perspektif etika bisnis Islam dan bagaimana pelaksanaan sistem konsinyasi Hamzah Batik Yogyakarta dengan supplier dalam perspektif etika bisnis Islam. Penelitian ini dikategorikan sebagai penelitian lapangan dengan menggunakan pendekatan kualitatif. Data diperoleh melalui wawancara langsung kepada reseller, supplier, dan jasa pengiriman. Selain itu juga diperoleh melalui pengamatan, dan dokumentasi. Hasil penelitian menunjukkan bahwa perilaku bisnis yang dijalankan oleh Hamzah Batik dalam perspektif etika bisnis Islam sudah cukup baik. Selain nilai dan etika bisnisnya, etika kepemimpinan yang ditunjukkan oleh pemimpinnya sudah baik. Pelaksanaan sistem konsinyasi Hamzah Batik dengan supplier dalam perspektif etika bisnis Islam yang dijalankan sudah cukup baik. Tidak ada pihak yang keberatan dan merasa dirugikan dalam kerjasama tersebut. Hak dan kewajiban telah dipenuhi oleh Hamzah Batik pada suppliernya. Tanggung jawab dan kepercayaan yang diberikan oleh supplier dijaga dengan baik, sehingga mereka dapat menjalankan kerjasama selama ini.

Kata Kunci : etika bisnis islam, reseller, konsinyasi

\section{PENDAHULUAN}

Setiap pengusaha akan berkompetisi pada dunia usaha yang dijalani untuk mempertahankan agar usahanya berjalan dengan lancar dan tidak tergeser dengan pengusaha yang lainnya, bahkan para pengusaha berusaha untuk memajukan usahanya dengan berbagai strategi. Beberapa strategi yang 
dilakukan oleh pengusaha diantaranya dengan meminimalisir harga produk, meningkatkan kualitas produk, dan berinovasi dalam mendesain produk, serta melakukan olah strategi dalam memasarkan produk. Pemasaran merupakan bagian terpenting dalam suatu usaha, baik jenis bidang usaha perorangan maupun perusahaan, karena pemasaran adalah ujung tombak bagi suatu usaha. Dalam hal olah strategi pemasaran, pengusaha akan berusaha semaksimal mungkin melakukan terobosan supaya produk yang dimiliki diterima oleh konsumen melalui model-model pemasaran. Salah satu langkah untuk menjalankan proses pemasaran yaitu dengan merencanakan pemasaran.

Bagi pengusaha, Yogyakarta merupakan tempat yang cocok untuk memasarkan barang hasil produksinya sendiri maupun barang hasil produksi orang lain, karena perkembangan perekonomian di Yogyakarta sangat pesat. Salah satu penyumbang terbesar dalam peningkatan perekonomian adalah banyaknya destinasi wisata alam maupun budaya yang ada di Yogyakarta. Tentunya dengan adanya destinasi wisata yang cukup banyak dapat menarik wisatawan domestik maupun mancanegara untuk berkunjung ke Yogyakarta. Hal tersebut dapat mempengaruhi tingkat penjualan barang dagangan yang dijadikan sebagai oleh-oleh atau buah tangan.

Hamzah Batik merupakan salah satu toko terbesar yang berada di jalan Margo Mulyo, jumlah supplier di toko ini mencapai 1.200 (Heru, 2018). Tentunya hubungan komunikasi antar supplier dengan reseller harus terjalin dengan baik supaya keduanya dapat berjalan dalam menjalankan usahanya. Hubungan kerja yang terjalin antara dengan supplier memang awalnya didasari saling membutuhkan, sehingga memutuskan untuk melakukan kerjasama. Namun kenyataannya, terkadang masih terdapat masalahmasalah dalam hubungan kerja, seperti munculnya konflik antar keduanya. Konflik dan kerjasama dapat saja mewarnai dalam suatu hubungan kerja karena hubungan kerja termasuk sebagai relasi sosial. Salah satu aspek yang perlu diperhatikan dalam hubungan kerja yaitu etika, perilaku, dan sifat yang ada di dalamnya. Penting bagi reseller dan supplier untuk mengedepankan etika dalam bisnis dan pekerjaan yang dijalankan.

Dengan etika yang terbentuk bisa dilihat bagaimana usaha tersebut dapat berkembang. Adanya etika dan perilaku yang baik di dalam hubungan kerja, maka akan sangat membantu dalam pertumbuhan usaha. Semakin baik etika terbentuk maka semakin baik pula usaha tersebut. Permasalahan yang menarik untuk diteliti yaitu; a). bagaimana perilaku bisnis Hamzah Batik Yogyakarta dalam perspektif etika bisnis Islam? b). bagaimana pelaksanaan sistem konsinyasi Hamzah Batik Yogyakarta dengan supplier dalam perspektif etika bisnis Islam?

Penelitian yang dilakukan oleh Anwar Arjanto tahun 2010 tentang "Pelaksanaan Perjanjian Konsinyasi di Mirota Batik Kaliurang Yogyakarta". Penelitian ini bertujuan untuk mengetahui bagaimana pelaksanaan perjanjian konsinyasi serta pengaturan hak dan kewajiban para pihak, risiko, 
kelalaian dan jangka waktu dalam kaitannya dengan bentuk perjanjian konsinyasi secara lisan di Mirota Batik Kaliurang Yogyakarta. Metode penelitian yang digunakan berupa metode hukum empiris, yaitu penelitian yang berfokus pada perilaku masyarakat hukum (law in action).

Teknik pengumpulan data dilakukan dengan cara wawancara bebas terpimpin serta penelitian kepustakaan. Hasil penelitian menunjukkan bahwa pada dasarnya pelaksanaan perjanjian konsinyasi di Mirota Batik Kaliurang sudah cukup baik, namun belum memberikan kepastian hukum bagi para pihaknya apabila terjadi suatu permasalahan seperti cara pembayaran, masalah kerugian dan resiko para pihak akibat kelalaian yang tak terduga karena tidak ada perjanjian tertulis diantara para pihak. Pengaturan hak dan kewajiban para pihak tentang risiko dan kelalaian dalam kaitannya dengan bentuk perjanjian konsinyasi secara lisan di Mirota Batik Kaliurang bagi para supplier masih kurang menjamin hak-hak para supplier karena mengenai cara pembayaran, pemberian potongan harga, dan retur barang kurang menguntungkan pihak supplier terutama bila ada overmacht dan resiko lebih dibebankan pada supplier, meskipun ada itikad baik dari Mirota Batik Kaliurang. (Arianto, 2010).

Penelitian yang dilakukan oleh Erlin Cahyani tahun 2015 tentang "Pelaksanaan Penjualan Sepeda Motor dengan Sistem Konsinyasi antara PT. Capella Dinamik Nusantara dengan Chanel Honda Tend di Kecamatan Kampar Kiri Menurut Tinjauan Ekonomi Islam". Tujuan Penelitian ini untuk mengetahui bagaimana pelaksanaan penjualan sepeda motor dengan sistem konsinyasi antara PT. Capella Dinamik Nusantara dengan Chanel Honda Tend di Kecamatan Kampar Kiri serta bagaimana tinjauan ekonomi Islam terhadap pelaksanaan penjualan sepeda motor dengan sistem konsinyasi antara PT. Capella Dinamik Nusantara dengan Chanel Honda Tend di Kecamatan Kampar Kiri. Metode penelitian yang digunakan yaitu kualitatif. Teknik pengumpulan data yaitu melalui observasi, wawancara serta dokumentasi. Hasil dari penelitian ini menyatakan bahwa pelaksanaan penjualan sepeda motor dengan sistem konsinyasi antara PT. Capella Dinamik Nusantara dengan chanel honda tend di Kecamatan Kampar Kiri tidak terdapat kelalaian ataupun ketidaktransparan dalam kerjasama. Dalam kerjasama tersebut tidak ada pihak yang merasa dirugikan oleh pihak yang lainnya. Kemudian pelaksanaan penjualan sepeda motor dengan sistem konsinyasi ini termasuk ke dalam akad wakalah. Sistem yang digunakan ini diperbolehkan dalam ekonomi islam karena penerapan kerjasama tidak bertentangan dengan prinsip ekonomi syariah. (Cahyani, 2015). Penulis memberi batasan penelitian yang tertuju pada toko Hamzah Batik yang berada di jalan Margo Mulyo nomer 9 kota Yogyakarta.

\section{KAJIAN LITERATUR Etika Bisnis Islam}

Etika dalam bahasa Yunani Kuno adalah ethikos atau ethos yang berarti muncul dari kebiasaan, adat, akhlak, watak, perasaan, sikap. Menurut 
Istiyono dan Ostaria, etika merupakan cabang utama filsafat yang mempelajari nilai atau kualitas. Etika mencakup analisis dan penerapan konsep seperti benar-salah, baik-buruk, dan tanggung jawab (Veithzal et al., 2012:2).

Menurut kamus, etika bermakna prinsip tingkah laku yang mengatur individu serta kelompok. Etika juga diartikan sebagai kajian moralitas, meskipun berkaitan dengan moralitas, namun tidak sama persis dengan moralitas. Etika adalah sejenis penelaahan itu sendiri, sedangkan moralitas merupakan subjek. Etika merupakan ilmu yang mendalami standar moral personal dan standar moral masyarakat (Veithzal et al., 2012:3).

Etika adalah keyakinan mengenai tindakan yang baik atau buruk yang mempengaruhi hal lainnya. Etika ini sangat erat hubungannya dengan perilaku manusia, apakah berperilaku etis ataukah berperilaku tidak etis (Abdurrahman, 2013:279). Etika bisnis adalah studi tentang baik buruknya mengenai sikap manusia, termasuk tindakan-tindakan relasi dan nilai-nilai dalam kontrak bisnis. Etika bisnis merupakan studi yang dikhususkan mengenai moral yang benar dan salah. Studi ini berkonsentrasi pada standar moral, sebagaimana diterapkan dalam kebijakan, institusi, dan perilaku bisnis. Standar etika bisnis tersebut diaplikasikan kedalam sistem dan organisasi yang digunakan masyarakat modern untuk memproduksi dan mendistribusikan barang dan jasa serta diterapkan kepada orang-orang yang ada di dalam organisasi (Veithzal et al., 2012:4).

Dalam Islam, etika bisnis adalah sejumlah perilaku etis bisnis (akhlaq al Islamiyah) yang dibungkus dengan nilai-nilai syariah yang mengedepankan halal dan haram. Jadi perilaku yang etis itu ialah perilaku yang mengikuti perintah Allah dan menjauhi larangan-Nya. Etika bisnis ini sudah banyak dibahas dalam berbagai literatur dan sumber utamanya yaitu Al-Quran dan As-sunnah. Pelaku bisnis diharapkan bertindak secara etis dalam berbagai aktivitasnya.

\section{Nilai-Nilai Etika Bisnis Islam}

Nilai-nilai atau prinsip umum etika bisnis dalam perspektif Islam yaitu etika bisnis yang mengedepankan nilai-nilai Al-Qur'an sebagai landasan (sumber) praktik bisnis yang dapat dijadikan tolok ukur etis atau tidaknya suatu aktivitas bisnis. Menurut Issa Rafiq Beekun nilai-nilai etika bisnis Islam antara lain (Harahap, 2011:78): Tauhid (unity), adil, kehendak bebas, tanggung jawab, dan ihsan. Menurut Faisal Badroen dkk, terdapat 4 nilai etika bisnis Islam, keempat nilai tersebut yaitu (Badroen dkk., 2006:106169): Kepemilikan dan kekayaan, distribusi kekayaan, kerja dan bisnis, halal dan haram. Seorang pakar manajemen dari Universitas Muhammadiyah Malang telah membahas tentang etika kepemimpinan (Tabroni, 2005:94106), diantaranya sikap etis terhadap sesama. Sikap etis terhadap sesama merupakan refleksi dari sikap etis terhadap Tuhan, karena manusia berkewajiban menjaga hubungan baik kepada Allah dan kepada sesama manusia (hablun minallah wa hablunminannas). Etika terhadap sesama ini 
dapat di kelompokkan dalam tiga kategori (Abdullah, 2013:39-61): 1). Etika yang berhubungan dengan sifat pribadi, 2). Etika yang berhubungan dengan sikap terhadap pergaulan dengan sesama seperti; silaturrahim, tawadhu (rendah hati). 3). Etika yang berhubungan dengan aktivitas berkarya seperti; Kerja sebagai ibadah, Musyarakah dan Ta'awun.

\section{Konsinyasi}

Dalam sebuah bisnis, perusahaan pasti akan memerlukan sebuah strategi baik dalam pemasaran maupun penjualan. Pengusaha harus memiliki strategi yang tepat untuk dikuasai agar usaha dan bisnisnya berjalan dengan lancar. Manajemen strategi adalah analisis sistematis dari faktor pada lingkungan eksternal dan lingkungan internal untuk memberikan dasar dalam manajemen yang optimal. Manajemen strategi memiliki beberapa tujuan diantaranya adalah untuk menjalankan dan mengevaluasi efektifitas dan efisiensi strategi yang sudah dipilih. Misalnya mengevaluasi kinerja, menyesuaikan strategi dengan lingkungan, dan merevisi setiap penyimpangan atau kesalahan yang ada saat pelaksanaan strategi. Jika kita menggunakan manajemen strategi kita akan mendapatkan sejumlah keuntungan. Salah satunya kita bisa mendapatkan keputusan terbaik karena ada banyak elemen yang masuk dalam proses manajemen. Melalui manajemen strategi ini juga perusahaan akan semakin fleksibel menghadapi perubahan yang terjadi terutama ancaman dan masalah dari luar. Manfaat lain yang terlihat adalah dalam segi kinerja. Karyawan dan seluruh aktivitas operasional akan lebih produktif dan efisien sehingga perusahaan akan lebih profitable. Strategi perusahaan harus mampu menjawab pertanyaanpertanyaan fundamental bisnis: apakah perusahaan harus berkonsentrasi pada bisnis tunggal atau membangun diversifikasi dengan kelompok usaha yang luas, dan lain sebagainya (Sampurno, 2013:15). Strategi harus menentukan pilihan-pilihan yang tepat dan terbaik hasilnya bagi perusahaan. Perusahaan memiliki space yang luas untuk merumuskan strategi bisnisnya. Inti dari proses manajemen strategis adalah mendefinisikan strategi organisasi. Selain itu manajemen strategis merupakan proses yang berkesinambungan artinya setiap langkahnya bertujuan untuk memenuhi semua target pada masa sekarang dan masa depan. Mulai dari segi organisasi, lingkungan dan pesaing kemudian menganalisa kembali strategi yang ada. Ada 4 langkah manajemen strategi yang dapat dilakukan oleh sebuah perusahaan: Mengevaluasi lingkungan, merumuskan strategi, menerapkan strategi, dan mengevaluasi strategi.

Diantara berbagai strategi yang dirumuskan oleh perusahaan, salah satunya adalah strategi pemasaran. Strategi Pemasaran (Marketing Strategy) adalah sebuah proses dalam menentukan target pasar dengan strategi bauran pemasaran yang saling terhubung. Target market adalah sekelompok pelanggan homogen atau pasar yang ingin segera dilayani permintaannya oleh pihak perusahaan. Sedangkan bauran pemasaran merupakan kumpulan variable yang telah disusun oleh perusahaan dalam rangka untuk 
memuaskan target market tersebut. Marketing Mix atau bauran pemasaran adalah kombinasi dari empat, macam variable atau kegiatan yang merupakan inti dari sistem pemasaran perusahaan, yaitu berupa: produk, struktur harga, kegiatan promosi serta sistem saluran distribusi.

Diantara berbagai macam strategi yang digunakan oleh perusahaan yaitu konsinyasi. Strategi konsinyasi merupakan salah satu strategi yang digunakan dalam melakukan penjualan. Berikut penjelasan lebih dalam mengenai konsinyasi:

\section{Konsep Dasar Penjualan Konsinyasi}

Dalam Kamus Besar Bahasa Indonesia, istilah konsinyasi diartikan sebagai kegiatan penitipan barang dagangan kepada agen atau orang untuk dijualkan dengan pembayaran kemudian (titip jual) (Kamus Besar Bahasa Indonesia Pusat Bahasa, 2008:726). Utoyo Widayat memberikan pengertian yang lebih lengkap mengenai penjualan konsinyasi, yaitu pengiriman atau penitipan barang dari pemilik barang kepada pihak lain yang bertindak sebagai agen penjualan dengan memberikan komisi atas penjualan yang dilakukan. Konsinyasi merupakan strategi penjualan dimana pemilik barang (konsinyor), berdasarkan perjanjian menitipkan barangnya kepada pihak yang bertindak sebagai agen penjual (konsinyi). Kepemilikan barangtetap berada pada pihak konsinyor sampai barang yang dititipkan terjual kepada pihak ke tiga (konsumen), dan atas jasanya pihak konsinyi memperoleh komisi.

Konsinyor menetapkan konsinyi sebagai pihak yang bertanggung jawab atas barang-barang yang dititip-jualkan ini hingga terjual kepada pihak ketiga (konsumen). Pihak konsinyi tidak memiliki kewajiban pada pihak konsinyor selain pertanggung jawaban atas barang-barang yang dititip-jualkan.

Unsur-unsur dalam perjanjian konsinyasi adalah: Adanya perjanjian, adanya pemilik barang, adanya pihak yang dititipi barang, adanya barang yang dititipkan, adanya ketentuan penjualan, dan adanya ketentuan komisi. Penjualan konsinyasi memiliki perbedaan dengan penjualan biasa. Pada penjualan biasa, umumnya hak milik dari barang telah berpindah tangan jika adanya perjanjian dan atau barang telah dikirim oleh penjual kepada pembeli, sedangkan pada penjualan konsinyasi hak milik barang tetap berada di tangan konsinyor. Hak milik baru berpindah tangan jika barang telah terjual oleh konsinyor kepada pihak lainnya.

Perbedaan yang lain adalah dalam hal biaya operasi yang berhubungan dengan barang yang dijual. Dalam transaksi penjualan biasa, semua biaya operasi yang berhubungan dengan barang yang dijual dibebankan kepada pihak penjual, tetapi dalam penjualan konsinyasi semua biaya yang berhubungan dengan barang konsinyasi dibebankan kepada konsinyor (pemilik barang) (Arifin, 1999:147-148).

Ketidakberpindahan hak milik dalam penjualan konsinyasi mengakibatkan biaya operasional dan uang penjualan menjadi kewajiban dan hak dari konsinyor, sedangkan agen akan menerima fee dari transaksi penjualan 
barang yang laku. Kepemilikan atas hasil penjualan tersebut diaplikasikan dengan penetapan harga dan komisi yang pasti bagi konsinyi. Sebagai penerima amanat, konsinyi tidak diperbolehkan untuk menggunakan uang hasil penjualan produk tersebut.

\section{Keuntungan Penjualan Konsinyasi}

Keuntungan Bagi Konsinyor (Pemilik Barang): 1). Untuk memperluas daerah pemasaran suatu produk oleh konsinyor yang disebabkan oleh beberapa hal, antara lain: memperkenalkan produk baru, dimana masyarakat belum mengetahui produk tersebut, dan untuk ekspansi penjualan di suatu daerah sangat mahal investasinya, 2). Konsinyor dapat mengontrol harga jual dari agen. Hal ini dimungkinkan karena agen hanya menjual dengan harga yang telah ditetapkan oleh konsinyor dan agen hanya menerima komisi atas penjualan tersebut, tanpa mengambil keuntungan dari harga jual barang konsinyasi (Widayat, 1999:126). 3). Barang konsinyasi tidak ikut disita apabila terjadi kebangkrutan pada pihak konsinyi sehingga resiko kerugian dapat ditekan (Arifin, 1999:147-148). 4). Konsinyor dapat memperoleh spesialis penjualan, terutama untuk penjualan gandum, ternak, dan hasil bumi. Imbalan untuk jasa seperti ini seringkali berupa komisi, yang dapat berupa persentase harga jual atau dapat juga berupa jumlah yang tetap untuk setiap unit batang yang terjual.

Keuntungan bagi Konsinyi (Agen) antara lain: 1). Konsinyi tidak dibebani resiko menanggung rugi bila gagal dalam penjualan barang- barang konsinyasi, 2). Konsinyi tidak mengeluarkan biaya operasi penjualan konsinyasi karena semua biaya akan diganti atau ditanggung oleh konsinyor, 3). Apabila terdapat barang konsinyasi yang rusak dan terjadi fluktuasi harga, maka hal tersebut bukan tanggungan konsinyi (hal ini sangat penting terutama bila barang konsinyasi tersebut berupa buah-buahan, atau produk pertanian lainnya), 4). Kebutuhan modal kerja dapat dikurangi, sebab konsinyi hanya berfungsi sebagai penerima dan penjual barang konsinyasi untuk konsinyor, 5). Konsinyi berhak mendapatkan komisi dari hasil penjualan konsinyasi (Arifin, 1999:147-148).

\section{Sistem Operasi Penjualan Konsinyasi}

Dalam melaksanakan penjualan konsinyasi, kedua belah pihak harus membuat kontrak perjanjian terlebih dahulu. Adapun isi dari kontrak perjanjian tersebut, antara lain: a). Beban-beban pengeluaran konsinyi akan ditanggung oleh konsinyor. Misalkan seperti beban pengangkutan, beban reparasi, beban kuli, beban sewa gudang, dan lain sebagainya. b). Kebijaksanaan harga jual dan syarat kredit yang harus dijalankan oleh konsinyi atas instruksi dari konsinyor. c). Komisi atau keuntungan yang akan diberikan oleh konsinyor kepada konsinyi. d). Laporan pertanggungjawaban oleh konsinyi kepada konsinyor yang dilakukan secara berkala atas barangbarang yang sudah terjual dan pengiriman uang hasil penjualan tersebut. e). After sales service (garansi) yang harus ditanggung oleh konsinyor atas 
barang-barang yang telah dijual oleh konsinyi. f). Hal- hal yang dianggap perlu oleh kedua belah pihak (Widayat, 1999:126-127).

Konsinyi memiliki beberapa hak dalam penjualan konsinyasi, yaitu; 1). Pihak konsinyi berhak memperoleh penggantian atas pengeluaran yang dibutuhkan berkaitan dengan barang konsinyasi dan juga berhak memperoleh imbalan atas penjualan barang konsinyasi. Pengeluaran yang dibutuhkan tergantung pada sifat barang konsinyasi dan biasanya meliputi pengangkutan, asuransi, pajak, penyimpanan, penanganan, reparasi di bawah garansi, dan beban lainnya yang biasanya ditanggung oleh pihak konsinyor. 2). Pihak konsinyi berhak menawarkan garansi biasa atas barang konsinyasi yang dijual, dan sementara itu pihak konsinyor terikat pada syarat pemberian garansi seperti ini. Konsinyi memiliki beberapa kewajiban yang harus dipenuhi, yaitu: 1). Pihak konsinyi harus melindungi barang-barang pihak pemilik dengan cara yang baik dan sesuai dengan sifat barang dan kondisi konsinyasi. Jika pihak konsinyi telah menerima instruksi khusus, maka ia harus melaksanakannya dengan baik untuk menghindari kewajiban. 2). Pihak konsinyi harus menjual barang konsinyasi dengan harga yang telah ditentukan atau jika tidak ada ketentuan mengenai harga, ia harus menjualnya dengan harga yang memuaskan kepentingan pihak pemilik. 3). Pihak konsinyi harus memisahkan barang konsinyasi dari barang dagangan lainnya. Jika pemisahan fisik ini tidak dapat dilakukan, maka barang konsinyasi ini harus diberi tanda khusus atau diselenggarakan catatan yang memungkinkan untuk menetapkan dengan segera barang konsinyasi ini. 4). Pihak konsinyasi harus mengirimkan laporan berkala mengenai kemajuan penjualan barang konsinyasi. Laporan ini berisi informasi mengenai barang konsinyasi yang diterima, barang konsinyasi yang dijual, harga jual, biaya penjualan, jumlah yang terhutang, dan jumlah (uang) yang dikirimkan (Widayat, 1999:126127).

\section{METODE PENELITIAN}

Pendekatan penelitian yang digunakan adalah pendekatan kualitatif, yaitu penelitian yang memiliki sasaran penelitian yang terbatas tetapi dengan keterbatasan itu dapat digali sebanyak mungkin data mengenai sasaran penelitian atau penelitian yang pemecahan masalahnya dengan menggunakan data empiris (Bungin, 2001:29). Penelitian ini termasuk dalam jenis penelitian lapangan (field research) dimana peneliti terjun ke lokasi penelitian dan mengamati serta mengadakan wawancara langsung kepada pihak-pihak terkait. Sumber data yang digunakan dalam penelitian ini terdiri dari data primer (pemilik usaha/toko), supplier serta pihak kurir/jasa pengiriman yang terkait dengan Hamzah Batik di Jalan Margo Mulyo Yogyakarta dan data sekunder (didapatkan dari literature, bacaan dan dokumentasi) dari pelaku usaha, seperti pemilik toko, supplier Hamzah Batik serta dari pihak jasa pengiriman barang yang terkait, dengan data yang relevan dalam penelitian ini). Memperoleh data yang diperlukan dengan menggunakan metode Observasi (Pengamatan), Interview (Wawancara), dan 
Dokumentasi. Penulis menggunakan metode penelitian deskriptif. Penelitian ini menjelaskan fenomena sosial yang ada dengan mengembangkan konsep dan menghimpun fakta, tetapi tidak melakukan pengujian hipotesis. Penelitian ini menggunakan teknik triangulasi sebagai alat pengecekan keabsahan data yang diperoleh.

\section{PEMBAHASAN}

\section{Perilaku Bisnis Hamzah Batik Yogyakarta dalam Perspektif Etika Bisnis Islam}

Perilaku bisnis adalah segala perbuatan atau tindakan yang dilakukan di dalam kegiatan usaha jual beli barang maupun jasa. Tindakan tersebut meliputi segala hal yang terkait dengan aktivitas usaha, baik secara langsung maupun tidak langsung, seperti pengambilan keputusan ataupun interaksi dengan karyawan dan konsumen serta suppliernya.

Berdasarkan hasil observasi yang telah dilakukan, perilaku bisnis yang ditampakkan oleh Hamzah Batik terlihat sudah cukup baik. Mengapa? Kami telah menganalisa kegiatan Hamzah Batik dengan perspektif etika bisnis Islam. Berikut akan kami paparkan terkait poin-poin yang telah sesuai dengan nilai-nilai etika bisnis Islam.

Diawali dengan kegiatan rutin dari Hamzah Batik sebelum mengawali kegiatannya, yaitu melaksanakan briefing. Memang hal ini wajar dan hampir semua perusahaan melakukan kegiatan tersebut. Namun yang perlu diketahui, dalam kegiatan briefing juga terselip adanya kegiatan do'a bersama sebelum mengawali pekerjaan. Tentunya hal ini merupakan hal yang baik dan patut dipertahankan, bahkan baik untuk ditiru oleh pengusaha lainnya. Doa bersama pra kegiatan adalah salah satu hal positif. Meskipun berbeda agama, do'a menyatukan berbagai karakter dalam tujuan yang sama, dalam hal ini yaitu untuk mensyukuri nikmat yang telah Tuhan berikan, diantaranya sampai saat itu mereka masih diberi kesehatan serta kesempatan untuk bekerja. Bekerja dalam perspektif Islam adalah bekerja yang terbaik (ahsanu amala). Oleh karena itu hidup dan kerja harus dijalani dengan sebaik-baiknya, penuh kesungguhan, komitmen dan dedikasi yang tinggi (Abdullah, 2013:39-61). Dengan adanya doa dalam briefing, merupakan salah satu cara untuk dapat menumbuhkan kesadaran dan melatih kepekaan perasaan, tentunya juga cara untuk selalu ingat akan Allah sebagai pemberi rahmat dan pencipta alam.

Setelah briefing berlangsung, para karyawan akan memulai bekerja sesuai dengan tugas dan tanggungjawab mereka. Sebagai salah satu seorang pemimpin, Kepala SPV akan standby dan turut mengawasi kinerja karyawannya. Tidak jarang ia akan menyambut dan berbincang ringan dengan supplier yang datang. Sudah tampak jelas, bahwasannya lingkungan kerja yang terbentuk cukup menyenangkan. Baik bagi kalangan intern karyawan maupun bagi kalangan ekstern supplier. Tidak ada gerak-gerik yang kaku diantara mereka. Semuanya saling berbaur dan tidak membedakan satu dengan lainnya. Dalam etika bisnis hal ini dapat disebut 
dengan musaawah. Pandangan bahwasannya semua manusia itu sama dan sederajat, tidak membedakan harta, martabat dan jenis kelamin (Abdullah, 2013:39-61).

Siapapun yang datang ke Hamzah Batik, akan mendapatkan sambutan yang ramah. Tidak memandang dia orang kaya ataupun bukan, tidak memandang dia laki-laki ataupun perempuan, supplier ataupun bukan. Semua pengunjung dan tamu mendapatkan pelayanan yang sama-sama menyenangkan. Disambut dengan senyum dan sapaan yang baik. Hal ini patut dipertahankan, karena tidak semua toko memiliki pelayanan seramah ini. Bahkan Hamzah Batik memberikan pelayanan dan fasilitas secara totalitas bagi konsumennya. Dimulai dari kostum karyawan, konsep "Kraton Ngayogyakarta" yang memanjakan mata, alunan gending yang membuat suasana lebih tenang, hingga sarana dan prasarana yang ada di dalam toko yang dapat menambah wawasan para pengunjungnya, seperti belajar membatik. Selain belajar secara praktek, juga terdapat beberapa benda yang memiliki sejarah yang dapat menambah wawasan pengunjung.

Semua itu bukti bahwasannya Hamzah Batik memberikan pelayanan secara sungguh-sungguh. Dalam etika bisnis Islam, hal ini menjadi bagian dari nilai Mujahid dan Mujtahid. Mujtahid dalam kata lain yaituberjuang secara psikis. Artinya Hamzah Batik secara psikis, berpikir sebaik mungkin untuk memberikan yang terbaik bagi pengunjung. Bagaimana agar konsep yang dimiliki Hamzah Batik dapat menyenangkan pengunjung dan sebagainya. Mujahid yaitu segala aktivitas yang dilakukan dengan sungguh-sungguh, penuh kesabaran dan keuletan untuk mengharap rahmat Allah. Untuk dapat mewujudkan apa yang telah dirancang dan dikonsep, maka perlu adanya tindakan secara real. Hingga akhirnya dapat dilihat bahwa Hamzah Batik dapat dinikmati oleh para pengunjung. Tentu itu semua bentuk dari kesungguhan dan keuletan dari pihak Hamzah Batik. Dalam sebuah hadist disabdakan yang artinya : "Sesungguhnya Allah menyukai jika salah seorang kamu mengerjakan suatu pekerjaan dengan tekun." (HR. Baihaqi). Maka berbahagialah mereka yang bersungguh-sungguh dan tekun dalam bekerja.

Segala keputusan dan tindakan harus menguntungkan manusia baik di dunia maupun di akhirat. Apa yang tampak dari kerja keras Hamzah Batik sudah tentu untuk memberikan keuntungan, baik bagi dirinya sendiri maupun bagi pihak luar, yaitu pengunjung dan suppliernya. Inilah salah satu bentuk dari nilai ihsan dalam etika bisnis Islam.Islam tidak membenarkan setiap tindakan yang dapat menimbulkan kerusakan terhadap diri, masyarakat, bahkan makhluk lain seperti binatang, tumbuhan, dan alam (Abdullah, 2013:39-61). Hamzah Batik juga memiliki program CSR dan kegiatan lain yang terkait langsung dengan masyarakat, seperti kegiatan S3 (Seribu Setiap Sabtu). Hal ini menunjukkan bahwa Hamzah Batik peduli dengan lingkungan sekitarnya. Dalam etika Islam kegiatan ini masuk dalam nilai sahiyyun. Sahiyyun adalah sikap peduli, empati dan merasa terpanggil untuk menolong sesama manusia yang sedang terbelenggu oleh kemiskinan, kebodohan, kedhaliman dan 
penyakit, dengan mendermakan sebagian dari harta yang dimiliki atas dasar keikhlasan dan mengharap ridha Allah (Abdullah, 2013:39-61).

Selain melihat dari sisi luar, selanjutnya melihat sisi lain dari Hamzah Batik dalam menyikapi karyawannya dari segi materi. Berbicara terkait materi, tentunya yang ada dalam benak kita adalah hal-hal seperti gaji, upah, bonus dan sebagainya. Sama halnya dengan perusahaan pada umumnya, Hamzah Batik memberikan gaji karyawannya sekali setiap sebulan. Selain gaji, ketika ada lemburan pun para karyawan mendapatkan upahnya sesuai dengan jam lembur. Hamzah Batik memberikan upah dengan menghitung 1 jam/lembur dan yang menyenangkan karyawan yaitu ada bonus tiap bulan, bonus diberikan sesuai tingkat penjualan. Bonus dalam hal ini termasuk salah satu dalam tiga bentuk tingkatan melampaui batas produksi. Yaitu bonus yang didapatkan berdasarkan jumlah unit produksi yang dihasilkan dalam satu kurun waktu tertentu (Sondang,2013:269).

Ternyata bukan hanya memberikan pelayanan yang terbaik bagi pengunjung, Hamzah Batik juga memberikan feedback yang terbaik untuk para karyawannya. Dengan begitu, Hamzah Batik telah memiliki nilai etika uswah hasanah. Maksudnya suri tauladan yang baik sebagaimana yang bisa ditiru dari pribadi Nabi Muhammad SAW dan Nabi Ibrahim as. Nabi Muhammad selalu menghargai kerja keras para sahabat yang telah mengucurkan keringatnya.

Uswah hasanah terbentuk atas dasar kesungguhan dan prestasi dalam perjuangan. Etos keteladanan ini sangat penting dikembangkan dalam rangka memajukan organisasi, terutama oleh para pemimpin. Dengan usaha yang telah berkembang puluhan tahun, Hamzah Batik termasuk perusahaan yang memiliki manajemen dan perilaku bisnis yang baik. Beberapa nilai etika bisnis Islam telah diterapkan dalam kegiatan sehari-hari Hamzah Batik.Baik etika terhadap karyawan maupun etika terhadap pengunjung dan suppliernya. Untuk itu, semua hal yang baik patut ditiru oleh perusahaan lain, dan yang kurang baik harus diperbaiki untuk dapat menjadi lebih baik.

\section{Sistem Konsinyasi Hamzah Batik Yogyakarta dalam Perspektif Etika Bisnis Islam}

Hamzah Batik 80\% suppliernya dalam jual beli menggunakan sistem konsinyasi. Artinya sistem titip jual dengan ketentuan dan syarat yang telah disepakati. Intinya, supplier menitipkan barang dagangannya kepada Hamzah Batik untuk dijualkan, namun hak kepemilikan belum berpindah kepada Hamzah Batik hingga berpindah ke pihak ketiga (konsumen), namun Hamzah Batik tetap bertanggung jawab atas barang-barang yang dititipjualkan tersebut dan atas jasanya pihak konsinyi memperoleh komisi ataupun hal serupa. Ada beberapa unsur yang seharusnya ada dalam konsinyasi, yaitu: Adanya perjanjian, adanya pemilik barang, adanya pihak yang dititipi barang, adanya barang yang dititipkan, adanya ketentuan penjualan, dan adanya ketentuan komisi.

Hamzah Batik belum memiliki perjanjian secara tertulis, hanya perjanjian dan peraturan secara lisan pada awal kesepakatan. Meskipun secara lisan, 
namun kesepakatan yang diatur cukup detail dan jelas bagi kedua pihak. Memang kurang baku, dan hal ini yang menjadikan sistem konsinyasi lebih fleksibel. Seperti dalam proses penagihan dan pembayaran pada supplier. Belum adanya perjanjian secara tertulis dapat menyulitkan kedua pihak ketika terjadi masalah. Meskipun sampai saat ini belum pernah terjadi masalah besar yang sulit untuk di atasi. Hanya saja sebagai perlindungan diri, alangkah lebih baik untuk bisa memiliki MoU atau perjanjian kepada supplier. Seperti yang dikatakan oleh bapak Agung dan bapak Heru, dalam waktu dekat akan diusahakan adanya perjanjian secara tertulis.

Meskipun belum ada perjanjian secara tertulis, sampai saat ini terkait proses dan sistem konsinyasi telah berjalan dengan baik. Hak dan kewajiban yang diperoleh Hamzah Batik sejauh ini telah dipenuhi dengan baik. Seperti halnya melindungi barang dagangan para supplier, membedakan secara fisik produk mereka dengan memberikan label, meskipun label asli dari pihak supplier dibiarkan tetap ada di produk tersebut. Hal ini memang sudah seharusnya dilakukan oleh pihak Hamzah Batik, mengingat bahwa kepemilikan produk tersebut belum berpindah pada Hamzah, melainkan hanya sebagai barang titipan. Sehingga label yang diberikan hanya sebagai pembeda dari barang-barang milik supplier.

Memenuhi hak dan kewajiban serta menempatkan pada posisinya dengan baik merupakan salah satu bentuk dari nilai adil. Adil yaitu "seimbang" atau dalam menyikapi sesuatu, termasuk dalam memenuhi hak dan kewajiban dengan baik, tidak meninggalkan salah satunya. Seperti yang telah diungkapkan, bahwasannya belum ada perjanjian secara tertulis dengan supplier dan Hamzah Batik. Namun begitu tidak menghambat sistem yang ada, proses penagihan dan pembayaran pada supplier pun tetap berjalan tepat waktu. Bahkan bisa lebih maju dari waktu yang ditentukan, menyesuaikan kondisi keuangan toko. Dari proses tersebut dapat kita lihat bahwa nilai etika al wafa sudah berjalan dengan baik. Artinya janji/hutang yang terjadi pada kedua pihak ditepati dengan baik. Tidak merugikan ataupun menyusahkan salah satu pihak. Ketika terjadi kesalahpahaman ataupun konflik dengan supplier, Hamzah Batik lebih mengambil tindakan dengan musyawarah untuk menyelesaikan masalahnya. Jika musyawarah telah dilakukan, alangkah lebih baik untuk melanjutkan berkomunikasi dengan Allah SWT. Dengan istikharah dan berdoa kepada Allah, hasil musyawarah ini dapat dilaksanakan dengan sebaik-baiknya.

Berdasarkan pada teori dan realita, sistem konsinyasi ini memiliki keuntungan bagi masing-masing pihak. Baik bagi konsinyi (Hamzah Batik) maupun bagi konsinyor (Supplier). Artinya kebijakan ini memiliki nilai Ihsan dalam etika bisnis Islam.Semua keputusan dan tindakan harus menguntungkan manusia baik di dunia maupun di akhirat. Kerjasama dibuat sedemikian rupa untuk meminimalisir kerugian yang dapat mereka alami. Hamzah batik merupakan salah satu perusahaan yang besar dengan ribuan supplier. Tentunya ini karena banyaknya supplier yang telah percaya kepada Hamzah Batik dan berani untuk membuat sebuah perjanjian kerjasama. 
Meskipun tidak semua supplier dapat diterima langsung, Hamzah batik memiliki karakter sendiri untuk menentukan suppliernya.

Dalam etika bisnis Islam ini disebut dengan amanah. Hamzah Batik telah diberikan kepercayaan oleh suppliernya untuk ikut serta mengembangkan bisnisnya. Dengan amanah yang diberikan tersebut, tentunya Hamzah Batik dapat menjaga dengan baik. Terbukti dari banyaknya supplier dan kerjasama yang cukup lama hinga puluhan tahun dengan mereka. Selain itu, berdirinya Hamzah Batik yang sudah puluhan tahun menjadi bukti bahwa mereka memiliki nilai tabligh, yaitu profesional. Sebuah perusahaan yang telah berdiri selama itu tentunya telah menjadi perusahaan yang profesional, baik dalam manajemenmaupun dalam memberikan pelayanan kepada para konsumen.

Secara keseluruhan, kerjasama yang dibangun oleh Hamzah Batik dan supplier merupakan bentuk dari nilai musyarakah dan ta'awun. Artinya mereka bukan hanya melakukan kerjasama atas dasar mencari keuntungan saja, melainkan ada unsur kebaikan di dalamnya. Yaitu untuk saling tolong menolong dengan sesama. Contohnya dengan adanya porsi $15 \%$ dalam pembinaan terhadap UMKM. Tidak semua perusahaan dapat bekerjasama dengan baik pada penggerak UMKM. Sedangkan UMKM sendiri sebenarnya cukup berpengaruh langsung terhadap masyarakat. Karena kebanyakan anggota dari UMKM adalah para ibu rumah tangga yang berusaha untuk memenuhi kebutuhan rumah tangga. Jadi secara tidak langsung, Hamzah Batik peduli dan membantu masyarakat kalangan menengah ke bawah.

Dalam penelitian ini, kurir atau jasa ekspedisi merupakan salah satu pihak yang ada di antara reseller dan supplier. Dari penjelasan kurir yang terkait juga terlihat bahwa kedua belah pihak selama menjalin kerjasama berjalan dengan baik-baik saja. Jarang sekali terjadi konflik selama bekerjasama. Meskipun pernah terjadi, masalah ataupun kesalahpahaman tersebut di selesaikan dengan musyawarah yang baik.

\section{SIMPULAN}

Hasil yang diperoleh dari penelitian mengungkapkan, bahwasannya hubungan kerja yang terjalin antara Hamzah Batik selaku reseller dengan suppliernya cukup baik. Hubungan kerja yang terjalin didasari rasa kekeluargaan dan kepercayaan, layaknya seperti hubungan antarasaudara sendiri. Keduanya saling memahami dan mengerti dengan keadaan usaha mereka. Sejauh yang peneliti amati, mayoritas supplier merespon dengan baik terkait kebijakan/strategi yang digunakan oleh Hamzah Batik. Banyak dari mereka yang menginginkan agar kerjasama dapat berjalan dalam jangka panjang, sehingga dapat saling menguntungkan. Selain itu, 15\% dari supplier merupakan bagian dari UMKM. Tentunya hal ini menjadi nilai positif bagi Hamzah Batik dan UMKM dalam mengembangkan usahanya masing-masing. Jelas terlihat bukan hanya sekedar menjalin kerjasama, namun disini juga ada nilai pemberdayaan bagi UMKM tersebut. Maka dari itu, hasil dari penelitian ini menunjukkan bahwa perilaku bisnis yang dijalankan oleh 
Hamzah Batik dalam perspektif etika bisnis Islam sudah cukup baik. Selain nilai dan etika bisnisnya, etika kepemimpinan yang ditunjukkan oleh pemimpinnya pun sudah baik.

Pemimpin serta organisasi dengan etika yang baik, dapat membuat mitranya lebih loyal, sehingga hubungan kerja yang terjalin akanberjalan lebih baik dan tahan lama, bahkan sampai puluhan tahun sehingga dapat memperlancar jalannya usaha. Hal ini juga akanberdampak pada pertumbuhan ekonomi di sekitarnya, karena dengan berkembangnya usaha tersebut maka UMKM atau homeindustry yang ada dapat kesempatan untuk menjadi mitra, serta dapat memotivasi berbagai pihak yang terkait.

Pelaksanaan sistem konsinyasi Hamzah Batik dengan supplier dalam perspektif etika bisnis Islamyang dijalankan pun sudah cukup baik. Tidak ada pihak yang keberatan dan merasa dirugikan dalam kerjasama tersebut. Hak dan kewajiban telah dipenuhi oleh Hamzah Batik pada suppliernya. Sistem yang dijalankan meskipun belum ada perjanjian secara tertulis namun tetap berjalan sesuai kaidahnya. Tanggungjawab dan kepercayaan yang diberikan oleh supplier dijaga dengan baik, sehingga mereka dapat menjalankan kerjasama selama ini.

Dalam penelitian ini, kurir sebagai salah satu pihak yang ada di antara reseller dan supplier mengungkapkan kerjasama yang baik yang dijalankan oleh mereka. Tidak banyak masalah ataupun konflik yang di alami. Sekalipun ada, masalah tersebut dapat diselesaikan dengan musyawarah yang baik. Hubungan kerja yang baik akan menciptakan perasaan aman dan tenang bagi mitra kerja dalam menjalankan kerjasamanya. Dengan begitu, pihakpihak terkait akan merasa lebih percaya ketika menjalin kerjasama, lebih saling menghormati dan menghargai serta tolong-menolong dalam kebaikan.

\section{DAFTAR PUSTAKA}

Abdullah, Ma'ruf. (2013). Manajemen Berbasis Syariah, Yogyakarta: Aswaja Pressindo.

Abdurrahman Nana Herdiana. (2013). Manajemen Bisnis Syariah dan Kewirausahaan, Bandung: Pustaka Setia.

Arifin. (1999). Pokok- Pokok Akuntansi Lanjutan, Ed. ke- 3, Cet. ke- 1. Yogyakarta: Liberty Yogyakarta.

Arjanto, Anwar. (2010). "Pelaksanaan Perjanjian Konsinyasi di Mirota Batik Kaliurang Yogyakarta", Skripsi Universitas Atma Jaya Yogyakarta.

Badroen, Faisal dkk. (2006). Etika Bisnis dalam Islam. Jakarta: Kencana Prenada Media Group.

Bungin, Burhan. (2001). Metode Penelitian Sosial: Format Kuantitatif dan Kualitatif. Surabaya: Airlangga University.

Cahyani, Erlin. (2015). Pelaksanaan Penjualan Sepeda Motor dengan Sistem Konsinyasi antara PT. Capella Dinamik Nusantara dengan Chanel Honda 
Perspektif Etika Bisnis Islam Pada Sistem Konsinyasi Dalam Strategi Reseller

Tend di Kecamatan Kampar Kiri Menurut Tinjauan Ekonomi Islam, Skripsi UIN Sultan Syarif Kasim Riau.

Hasil wawancara dengan Bapak Heru selaku supervisor dan kepala gudang Hamzah Batik jalan Margo Mulyo No. 09 Yogyakarta pada tanggal 5 Juli 2018.

P Siagian, Sondang. (2013). Manajemen Sumber Daya Manusia. Jakarta: Bumi Aksara.

Pusat Bahasa. (2008). Kamus Besar Bahasa Indonesia Pusat Bahasa. Jakarta: PT. Gramedia Pustaka Utama.

Rivai Veithzal, dkk. (2012). Islamic Business and Economic Ethics, Jakarta: Bumi Aksara.

S. Harahap, Sofyan. (2011). Etika Bisnis dalam Perspektif Islam. Jakarta: Salemba Empat.

Sampurno. (2013). Manajemen Stratejik: Menciptakan Keunggulan Bersaing yang Berkelanjutan. Yogyakarta: Gajah Mada University Press.

Tabroni. (2005). Etika Spiritual Leadership. Malang: UMM Press.

Widayat, Utoyo. (1999). Akuntansi Keuangan Lanjutan: Ikhtisar Teori dan Soal, Ed. Revisi. Jakarta: LPFE UI. 
Muhammad Khoirul Fikri

Halaman ini sengaja dikosongkan 